\title{
Juvenile fish caging as a tool for assessing microplastics contamination in estuarine fish nursery grounds
}

\author{
Kazour Maria 1, 2, ${ }^{*}$, Jemaa Sharif ${ }^{2}$, El Rakwe Maria ${ }^{3}$, Duflos Guillaume ${ }^{4}$, Hermabassiere Ludovic ${ }^{4}$, \\ Dehaut Alexandre ${ }^{4}$, Le Bihanic Florane ${ }^{5}$, Cachot Jerome ${ }^{5}$, Cornille Vincent ${ }^{1}$, Rabhi Khalef ${ }^{1}$, \\ Khalaf Gaby ${ }^{2}$, Amara Rachid ${ }^{1, *}$
}

${ }^{1}$ Laboratoire d'Océanologie et de Géosciences, Université Littoral Côte d'Opale, CNRS, Université Lille, UMR 8187, LOG, 32 Avenue Foch, Wimereux, France

${ }^{2}$ CNRS-L, National Center for Marine Sciences, PO Box 534, Batroun, Lebanon

3 IFREMER, Laboratoire Détection, Capteurs et Mesures (LDCM), Centre Bretagne, Plouzané, France

${ }^{4}$ ANSES, Laboratoire de Sécurité des Aliments, Boulevard du Bassin Napoléon, 62200 Boulogne, France

${ }^{5}$ Laboratory EPOC UMR CNRS 5805, University of Bordeaux, Allée Geoffroy Saint-Hilaire, 33615

Pessac, France

* Corresponding authors : Maria Kazour, email address : maria.kazour@univ-littoral.fr ; Rachid Amara, email address : rachid.amara@univ-littoral.fr

\begin{abstract}
:
Estuaries serve as nursery grounds for many marine fish species. However, increasing human activities within estuaries and surrounding areas lead to significant habitat quality degradation for the juveniles. In recent years, plastic pollution has become a global environmental issue as plastic debris are found in all aquatic environments with potential adverse impacts on marine biota. Given the important ecological role of estuaries and implications of microplastics (MP) in ecosystems, here we assess the occurrence, number, size, and polymer types of MP ingested by wild and caged juvenile European flounder (Platichthys flesus). We deployed caged fish for 1 month at five sites in three estuaries in the eastern English Channel. The Seine estuary, heavily impacted by manmade modifications and one of the most contaminated estuaries in Europe, was compared to two smaller estuaries (Canche and Liane) less impacted by industrial activities. We found that juvenile flounders $(7-9 \mathrm{~cm})$ were vulnerable to plastic ingestion. Seventy-five percent of caged fish and $58 \%$ of wild caught fish had the presence of MP items in their digestive tract. Fibers (69\%) dominated in the fish's digestive tract at all sites. An average of $2.04 \pm 1.93 \mathrm{MP}$ items were ingested by feral juvenile flounder and $1.67 \pm 1.43$ by caged juvenile flounder. For the caged fish, the three sites impacted by wastewater treatment plant (Liane, Le Havre harbor, and Rouen) were those with the highest percentage of individuals that has ingested MP items. Most of the isolated items were fibers and blue in color. Polymers identified by micro Raman spectroscopy were polycaprolactam, polyethylene terephthalate, and polyurethane. Although other environmental factors may have affected caged fish condition and mortality, we found no significant correlation with the number of ingested MP. However, the high occurrence of MP ingested by juvenile fish on nursery grounds raises concerns on their potential negative effects for fish recruitment success and population renewal. Finally,
\end{abstract}


this study describes, for the first time, the feasibility of using caged juvenile fish as an assessing tool of MP contamination in estuarine nursery grounds.

Keywords : Microplastics, Caging, Juvenile flounder, Estuaries, Raman spectroscopy 


\section{Introduction:}

The occurrence of microplastics (defined as particles $<5 \mathrm{~mm}$ in their longest size) in aquatic ecosystems (marine and freshwater) is well documented (for review: Wright et al. 2013; Cole et al. 2014; Van Cauwenberghe et al. 2015). Due to their different densities ranging from $0.9 \mathrm{~g} / \mathrm{cm}^{3}$ (Polystyrene and Polypropylene) to $1.39 \mathrm{~g} / \mathrm{cm}^{3}$ (Polyethylene terephtalate and Polyvinyl chloride), they are either found at the water surface layer (Ivar do Sul and Costa 2014) or sunk to the bottom (Woodall et al. 2014). Therefore, both pelagic (Collard et al. 2015) and benthic species (McGoran et al. 2017) may be affected by these plastic pieces. Many aquatic species have now been reported to ingest plastics from the environment. Microplastics (MP) can enter the food web of aquatic environments via direct or indirect pathways, including inhalation, entanglement, ingestion from incidental capture, being mistaken for food, or by the ingestion of a prey species already containing microplastics (Au et al. 2017; Setälä et al. 2018). Because of their ubiquitous presence, their small size, and the chemical pollutants existing in plastics (such as additives or adsorbed contaminants from the surrounding environment), MP could threaten the health of various organisms (Auta et al. 2017). Indeed, the ingestion of MP may cause both direct physical and toxicological effects. Physical effects include internal abrasions and gut blockages, which may lead to starvation (Wright et al. 2013; Gall and Thompson 2015). Among other potential effects, the ingestion of MP instead of food may lead to a delay in growth (e.g. due to starvation), a decrease in the individual fitness, and even causing death, with likely negative effects on population dynamics (Rochman et al. 2013; Luis et al. 2015; Lönnstedt and Eklöv 2016; Critchell and Hoogenboom 2018). In recent years, an increasing number of studies have been carried out to assess the occurrence and effects of MP in marine fish species (e.g., Lusher et al. 2013, 2017; Nadal et al. 2016; Neves et al. 2015). However, few studies have concerned estuarine fish (but see McGoran et al. 2017; Vendel et al. 2017; Bessa et al. 2018; Ferreira et al. 2018). These studies focused mainly on tropical estuaries and on wild-caught adult fish. Estuaries are known as essential fish habitats because they act as nursery grounds for juveniles of various marine fish species, providing refuge, food, and habitat (Beck et al. 2001; Selleslagh and Amara 2008). Despite their ecological importance, estuaries are amongst the most modified and threatened aquatic environments (Halpern et al. 2008). These areas are exposed to a growing anthropogenic pressure, particularly through acute and chronic pollutions such as 
industrial and wastewater effluents discharge. Estuarine ecosystems have been identified as microplastics hotspots (Browne et al. 2011, Wright et al. 2013).

In order to compare different sites or estuaries, it is necessary to investigate the same species of the same age range at each site. However, it is almost impossible to find a species that is present in all sites of interest. To cope with this problem, transplant experiments can be conducted (Oikari 2006; Kerambrun et al. 2011). Caging experiments present many advantages (Oikari 2006) including the selection of well-characterized homogenous organisms (number, age, size, weight, and sex) and the control of their exposure (location, time, and season). In addition, this technique offers advantages over simple field collection of organisms since it is possible to study an impacted zone surrounding a relatively precise outlet discharging pollutants. Such approach was successfully used to monitor microplastics contamination in mussels (Catarino et al. 2018; Railo et al. 2018). To the best of our knowledge, juvenile fish caging, as a tool for assessing estuarine microplastics contamination, has not been investigated before.

The aims of this research were to estimate the occurrence, number, size and polymer types of MP ingested by wild and caged juveniles European flounder (Platichthys flesus) and to test the caging method as a tool to quantify and assess MP contamination of juvenile fish. We also tested the hypothesis that ingested plastic adversely affects the condition and survival of caged fish. The European flounder, was selected for the study because it is one of the most important components of the juvenile demersal fish assemblage in European estuarine waters (Selleslagh et al. 2009). This benthic species is commonly used for environmental monitoring studies in northern European waters (e.g. Marchand et al. 2003; Amara et al. 2009).

\section{Materials and methods:}

\subsection{Study sites}

The study area was located along the French coast of the Eastern English Channel. Three estuaries were investigated: the Liane, Canche and Seine estuaries (Fig 1). Liane and Canche are small estuaries with small freshwater input: 3 and $7 \mathrm{~m}^{3} \cdot \mathrm{s}^{-1}$, respectively. The Liane estuary is mainly affected by a municipal wastewater treatment plant (WWTP) that treats the wastewater of ca. 200,000 inhabitants. The Canche estuary is not impacted by any important human activity 
and is considered as clean estuary (Amara et al. 2009). The Seine estuary, the largest one in the English Channel (150 $\mathrm{km}^{2}$ at high tide), displays a strongly urbanized and industrialized basin since it concentrates approximately $40 \%$ of the economic activity of France. In spite of significant efforts to restore environmental quality during the past few decades, it remains one of the most chemically polluted estuaries in Western Northern Europe (Dauvin et al. 2007).

\subsection{Sampling and caging experiment}

In September 2017, 150 0-group juveniles' flounder (7- $9 \mathrm{~cm}$ total length, TL) were collected in the Canche estuary using a small beam trawl. After capture and before deployment in cages, the fish were acclimatized for one week in a 500 liter aquarium supplied with an open seawater circuit and were daily fed on frozen Mysidacea and brine shrimps (Artemia sp.).

One day before the caging experiment, flounders were anaesthetized (Eugenol $35 \mathrm{mg} / \mathrm{L}$ ), weighed (to the nearest $1 \mathrm{mg}$ ), measured for total length (within $0.1 \mathrm{~mm}$ ), and individually marked (Visual Implant Tag, $1.2 \mathrm{~mm} \times 2.7 \mathrm{~mm}$, Northwest Marine Technology).

Cage placement was carried out the $12^{\text {th }}$ and $13^{\text {th }}$ of September 2017 at five sites. Three sites were chosen in the Seine estuary: Rouen $\left(49^{\circ} 22.995^{\prime}\right.$ N; $\left.01^{\circ} 00.676^{\prime} \mathrm{E}\right)$, Le Havre harbor $\left(49^{\circ} 28\right.$. $\left.853^{\prime} \mathrm{N} ; 00^{\circ} 05.590^{\prime} \mathrm{E}\right)$ which are both affected by a wastewater treatment plant (Emeraude and Edelweisse, respectively), and Fosse Nord $\left(49^{\circ} 27.328^{\prime} \mathrm{N} ; 00^{\circ} 07.4^{\prime} 3^{\prime} \mathrm{E}\right)$ in the main channel of the estuary. Two other cages were put in the Canche $\left(50^{\circ} 30.982^{\prime} \mathrm{N} ; 01^{\circ} 37.852^{\prime} \mathrm{E}\right)$ and the Liane estuaries $\left(50^{\circ} 42.08^{\prime} \mathrm{N} ; 01^{\circ} 36.59^{\prime} \mathrm{E}\right)$. The number of fish placed inside the cages was between 15 and 20 fish per cage. The cages were made of Stainless steel without any plastic material to avoid contamination. Their length was of $1 \mathrm{~m}$, whereas their width and height were of $0.6 \mathrm{~m}$. Their mesh size was $15 \mathrm{~mm}$ allowing water circulation and enough space for fish to feed. The cages were fixed to the bottom with a screw anchor secured by scuba-divers at depths varying between 4 to $8 \mathrm{~m}$. Following the one month caging exposure, all fish were rapidly transferred to the laboratory, identified (tag), weighed, and measured. In order to evaluate the potential effect of microplastics contamination on juvenile fish, we calculated the Fulton's K condition index as an indicator of the fish general well-being.

$\mathrm{K}=100 \mathrm{~W} / \mathrm{L}^{3}$; where $(\mathrm{W})$ is the body mass $(\mathrm{mg})$ and $(\mathrm{L})$ is the total length $(\mathrm{mm})$.

Along with the caging experiment, feral juvenile flounders of the same age (G0) and size (7- 9 cm TL) were collected in September 2017 at two sites near the caging sites: the Canche and the 
Seine (Fosse Nord) estuaries in order to compare microplastics contamination between feral and caged fish. Although we sampled in all the sites used for the caging experiment, we did not capture flounder at the other three sites.

\subsection{Microplastics analysis}

Flounders were dissected under a laminar flow hood and their digestive tract (stomach and gut) were weighted, preserved in aluminum foil, and conserved at $-20^{\circ} \mathrm{C}$ until analysis. Cotton laboratory coats were worn at all times during samples analysis, dissecting instruments were cleaned with MilliQ water after every dissection, and the usage of plastic material was avoided. Prior to digestion, digestive tracts were taken out of the freezer and left to thaw. All the following procedures were done under a laminar flow hood. Solutions used (besides MilliQ water) were filtered three times using glass fiber filters GF/A with a pore size of $1.6 \mu \mathrm{m}$ (Whatman, France). All materials were cleaned with MilliQ water, filtered ethanol 70\%, and MilliQ water, respectively. The digestive tract of each individual was taken and emplaced in an Erlenmeyer with a volume of $100 \mathrm{~mL}$ of filtered $\mathrm{KOH} 10 \%$ (m/v, ChimiePlus, France) (Dehaut et al. 2016; Hermsen et al. 2017). With every digested lot constituted of 9 erlenmeyers each one containing one digestive tube; one control was made containing only $100 \mathrm{~mL}$ of $\mathrm{KOH}$ and has undergone the same digestion conditions as the samples. These Erlenmeyers were put on a heating magnetic stirrer for 24 hours at $60^{\circ} \mathrm{C}$. Then, each solution was vacuum filtered on a 47 mm GF/A filter (Whatman, France). Each filter was put inside a clean glass Petri dish and surrounded with parafilm. Filters remained covered until Raman analysis to avoid prolonged exposure to atmospheric contamination from dust.

\subsection{Stereomicroscope observation and micro-Raman spectroscopy analysis}

After digestion, filters were observed under 120x magnification using Leica M165 C Stereomicroscope and images of plastic items recovered were taken with a Leica M170 HD camera and LAS (Leica application suite) software. The filters were methodically examined from left to right along the first row, right to left along the second row and so on, to prevent 
181

182

183

184 185

186

187

188

189

190

191

192

193

194 195

double-counting of MP. Microplastics were classified according to their physical characteristics into fibers, fragments, and films. They were counted, measured at their longest dimension, and their color was noted. During stereomicroscope inspection, samples remained closed inside the Petri dish. Whereas for Raman analysis, filters were placed inside and the machine was directly closed to avoid airborne contamination.

Five filters containing potential MPs, were randomly selected per site and analyzed using a Micro-Raman Xplora Plus (HORIBA Scientific ${ }^{\circledR}$ France). Each filter corresponds to the digestive tract of an individual fish. Two lasers were used with a wavelength of $532 \mathrm{~nm}$ and 785 $\mathrm{nm}$ with a range of 200-3500 $\mathrm{cm}^{-1}$. Two objectives (Olympus, Rungis, France) were used: $\mathrm{x} 10$ and x100. Filters were either analyzed manually or using ParticleFinder module for LabSpec (Frère et al. 2016). This latter is an automated application that locates particles and performs Raman analysis on these particles by moving each particle beneath the laser spot. Each particle spectrum is compared to Database polymer identification software (KnowItAll, BioRad®) and a personal library made with specific polymers obtained from Goodfellow (France). The identification is considered correct when the HQI (Hit Quality Index) was above 80 (ranging from 0 to 100).

\subsection{Statistical analysis}

Data were analysed using XLSTAT software. The conditions for applying parametric tests, i.e. homogeneity of variance and normality, were verified using Fisher and Shapiro-Wilk tests respectively. As result of these tests, non-parametric tests (Kruskal-Wallis (KW) and MannWhitney U-test) were used in order to highlight significant differences of MP contamination in flounder caged at different locations and with feral individuals collected at the same site. Differences between groups were considered as significant when $\mathrm{p}<0.05$. The $\mathrm{KW}$ test was followed by a post hoc test Multiple Comparisons of p-value (MCP) when it was significant at $p$ $<0.05$. Data are expressed in mean \pm standard deviation $(\mathrm{SD})$.

\section{Results}




\subsection{Caging experiment}

After one-month of exposure, all the cages were recovered. The number of fish in each cage was counted and survival percentage was calculated. The mean percentage of survival was $70.59 \%$ and all sites had a high survival rate $(>70 \%)$ except for the Canche estuary where the cage was partially silted and, therefore, having the lowest survival percentage of $37 \%$ (Fig. 2). The Fulton's K condition factor of each individual flounder analyzed varied between 0.55 and 1.39 mg. $\mathrm{mm}^{-3}$ (mean value $0.79 \pm 0.11 \mathrm{mg} \cdot \mathrm{mm}^{-3}$ ). Individuals from Le Havre Harbor and Fosse Nord had a significantly lower K compared to the Canche and Rouen (Fig. 2).

\subsection{Microplastics occurrence in fish}

A total of 86 fish (feral and caged) were analyzed. In all the examined fish, 149 items were identified on the filters using the stereomicroscope as potential MP consisting of 103 fibers, 43 fragments, and 3 films (Fig. 3). Fibers (69\%) dominated in fish's digestive tract whereas films were only observed in feral fish in Fosse Nord and caged fish in Le Havre Harbor with an average number of $0.2 \pm 0.42$ and $0.083 \pm 0.28$, respectively. An average of $75 \%$ of caged fish had at least one MP items (fragments, fibers, and films) in their digestive tract (64 caged fish analyzed) with Le Havre harbor having the highest percentage of $91.7 \%$ (Fig. 4). For the feral fish, Fosse Nord had a higher percentage of contaminated fish $(80 \%)$ than that of the Canche estuary (36.4\%) (Fig. 4). An average of $2.04 \pm 1.93$ items were ingested by feral juvenile flounder and $1.67 \pm 1.43$ in caged juvenile flounder (Fig. 5). Although not significantly different (Mann-Whitney U-test, $\mathrm{p}=0.097$ ), the number of MP items in feral fish was higher in the Seine estuary (Fosse Nord) compared to the Canche estuary. For the same site, where both feral and caged fish were analyzed, the number of MP items ingested by feral fish was higher but only significant for Fosse Nord (Mann-Whitney U-test: Fosse Nord $p=0.011$; Canche $p=0.970$ ) than in caged fish (Fig. 5). For caged fish, the number of ingested items was highest in the Liane (2.47 \pm 1.51) and lowest in the Canche $(0.90 \pm 0.99)$ and Fosse Nord $(0.93 \pm 0.70)$. A significant difference was only observed between the Liane and Fosse Nord (KW test, $\mathrm{p}=0.004)$. There was no significant correlation between juvenile fish condition and the number of MP ingested at each site $(\mathrm{p}=0.336)$. In addition, the mortality rate observed in caged fish at each site is not correlated 
to the mean number of MP ingested $(\mathrm{p}=0.09)$. On the contrary, the sites with the lowest mortality (Liane, Le Havre Harbor and Rouen) corresponded to those with the highest number of MP ingested.

\subsection{Characterization of microplastics}

Color distribution of ingested items was mostly uniform across all analyzed sites, blue MP being the most common (54\%), followed by red (21\%) and black (13\%), while other colors such as pink, white and green were less frequent (Fig. 6a). The size of fibers ranged from $70 \mu \mathrm{m}$ to 4510 $\mu \mathrm{m}$ and for the fragments between $5 \mu \mathrm{m}$ and $66 \mu \mathrm{m}$. Fragments, films, and fibers were divided into several size classes: 0-200 $\mu \mathrm{m}, 200-400 \mu \mathrm{m}, 400-600 \mu \mathrm{m}, 600-800 \mu \mathrm{m}, 800-1000 \mu \mathrm{m}$, and > $1 \mathrm{~mm}$. Most of the isolated MP belonged to the smallest $(<200 \mu \mathrm{m})$ and largest $(>1 \mathrm{~mm})$ size class with respectively $35.6 \%$ and $24.2 \%$ while the other size classes had a similar distribution (Fig. 6b). There was no inter-sites difference in ingested item size except for the Canche (for feral and caged fish) where the largest size class dominates.

Five filters were randomly selected from each site and analyzed using $\mu$-Raman to confirm if the particles extracted were plastics by identifying their chemical composition. In the Raman spectrum of fibers, only fluorescence could be observed, although an optimization including the reduction of laser power and bleaching was attempted. In addition, for the colored items, the spectrum was hidden by the additives (dyes) existing on particles. Only 37 fragments were successfully analyzed with the Raman. Among these fragments, eleven were identified as polymers: Polycaprolactam (PA-6), Polyethylene Terephtalate (PET) and Polyurethane (PUR). For colored particles (blue and green), the observed spectrum was that of the dye. Two corresponding spectra were observed: Copper Phthalocyanine (specific of blue items and the most frequent obtained spectrum) and Hostasol Green G.K (which is characteristic of green items). Fibers were not identified with the Raman due to its delicate procedure when identifying thin and small fibers; suggesting that microplastics ingestion might have happened in lower proportion than mentioned above.

The spectral range of PA-6, PET, PUR and Copper phthalocyanine are presented in the Supplementary Material: The PA-6 having its characteristic peaks between $900 \mathrm{~cm}^{-1}$ and 1500 $\mathrm{cm}^{-1}$, and $2500 \mathrm{~cm}^{-1}$ and $3000 \mathrm{~cm}^{-1}$. Whereas for PET, characteristics peaks were between 600 $\mathrm{cm}^{-1}$ and $1700 \mathrm{~cm}^{-1}$ and $3000 \mathrm{~cm}^{-1}$ and $3400 \mathrm{~cm}^{-1}$ (decreased trend). 
274 When excluding the colored items, we observed that in wild caught fish from the Canche and

275 Fosse Nord, the MP items were made of Copper Phthalocyanine and PA, respectively. In caged

276 fish, the MP items were made of PA in the Liane and in the Canche. Whereas for the three Seine

277 estuary sites, PET was the predominant polymer (61\%) followed by PA and PUR (Fig. 7).

\section{Discussion}

This research identified and quantified, for the first time, the presence of ingested microplastics in feral and caged juvenile fish $(\leq 9 \mathrm{~cm}$ TL) from the Eastern English Channel estuaries highlighting their potential negative effects. In this region, estuaries provide nursery areas for a wide variety of marine fish species including commercially important fish such as seabass, sole, plaice, and flounder (Selleslagh et al. 2009). Estuaries are also used by adults as reproduction, migration, and feeding grounds (McLusky and Elliott 2004). These ecosystems play an important role in maintaining biodiversity and constitute an essential fish habitat supporting future recruitment to adult fish stocks (Beck et al. 2001). However, increasing human activities within estuaries and surrounding areas, lead to a significant habitat loss for the juveniles and a decrease in the quality of the remaining habitats as was reported for the Seine estuary (Gilliers et al. 2006; Courrat et al. 2009).

292 Several studies have identified the presence of microplastics in the digestive tracts of wildcaught fish. However, the level of fish contamination in transitional systems such as estuaries is less known. Most of the studies were conducted in tropical estuaries (Dantas et al. 2012; Ramos et al. 2012; Possatto et al. 2011; Vendel et al. 2017; Bessa et al. 2018; Ferreira et al. 2018). Only two studies have been conducted in temperate estuaries: McGoran et al. (2017) in River Thames, UK and Bessa et al. (2018) in the Mondego estuary (Portugal). We found that estuarine juvenile flounders are vulnerable to plastic ingestion: $75 \%$ of caged fish and 58\% of wild caught fish had the presence of MP items in their digestive tract. In a recent study, McGoran et al. (2017) found that over $70 \%$ of River Thames adults European flounder had ingested plastics. These results are high compared to previously published estimates of plastic ingestion by marine fish (both pelagic and demersal species) which ranged from $2.6 \%$ in the North Sea (Foekema et al. 2013), 18\% in the Central Mediterranean (Romeo et al. 2015), 28\% in the Adriatic Sea (Avio et al. 2015), and $41 \%$ in the Eastern Mediterranean (Guven et al. 2017). In comparison with our study area, 
Lusher et al. (2013) reported that $37 \%$ of fish in the English Channel had ingested MP, whereas this ingestion was only 5.4\% in the southern North Sea (Foekema et al. 2013). The high occurrence of MP in estuarine fish suggests that MP are more common within estuarine water column and sediments than in the marine environment (Anderson et al. 2018). These transitory waters are important transport routes of MP into the marine environment since about $80 \%$ of marine plastics are derived from land-based anthropogenic sources (Andrady 2011; Schmidt et al. 2017). Mean concentration in rivers is roughly 40-50 times higher than the maximum concentration observed in the open ocean (Schmidt et al. 2017). Estuaries are also dominated by fine sediments in the subtidal and intertidal mudflats which can act as important short-term and longer-term sinks for MP (Browne et al. 2010; Horton et al. 2017; Leslie et al. 2017) as often occurs with other contaminants such as metals, hydrocarbons, and pesticides. For example, in two South Carolina Estuaries, intertidal sediments contained a greater amount of microplastics than the sea surface microlayer (Gray et al. 2018). Estuaries are considered as hotspots of MP contamination (Browne et al. 2011; Wright et al. 2013). This means that estuarine fish are exposed to a higher concentration of MP and, thus, have a higher probability of MP ingestion than marine species.

Several studies showed higher frequencies of fibers compared with other forms of microplastic in a variety of marine environments (see Cole et al. 2013 and Wright et al. 2013). In most studies, fibers were the dominant type of microplastics ingested by estuarine fish (> 90\%) (Ferreira et al. 2018; Bessa et al. 2018). In our study, fibers (69\%) constituted the majority of items found in the digestive tract of the juvenile flounders. This percentage was similar to the one observed in flounders (70\%) from the River Thames (McGoran et al. 2017). The dominance of fibers seems to be a typical pattern for many other demersal fish in other locations (e.g. Lusher et al. 2017; Bessa et al. 2018). As suggested by Ferreira et al (2018), filaments may resemble as natural food items for juvenile flounders (such as nematodes, amphipods, and polychaetes) resulting in mistaking them as preys. The high contamination of fibers in estuarine organisms supports Jabeen et al. (2017) suggestion that freshwater systems and estuaries (transitional systems) are more likely to be contaminated by fibers. For example, in the Solent estuary (UK) more than $80 \%$ of particles collected in the water column were fibers (Gallagher et al. 2016). In the Seine River water, Dris et al. (2015) found that fibers were dominant with an average of 45 fibers $/ \mathrm{m}^{3}$ and 0.54 fragments $/ \mathrm{m}^{3}$ in the water column. Even though the main 
sources of fibers in these systems are not fully determined, they could be related with Wastewater Treatment Plants (WWTPs) (Browne et al. 2011; Klein et al. 2015). While they are able to retain a high proportion, e.g., from $83 \%$ to $95 \%$, WWTPs effluents still constitute an important source of fibers (Dris et al. 2015; Leslie et al. 2017). Fibers of all colors were found in the gut of juvenile flounders, but blue fibers were predominant. This is also a typical observation, reported worldwide, for estuarine fish species (Possatto et al. 2011; Vendel et al. 2017, Bessa et al. 2018; Ferreira et al. 2018) and also for marine and freshwater species (Lusher et al. 2017). A recent study investigating the removal of microplastics by WWTPs determined that blue microplastic fibers were most often released from WWTPs (Conley 2017). During the caging experiment, the three sites (Liane, Le Havre Harbor, and Rouen) that are affected by wastewater treatment plant effluent presented the highest ingested number of fibers per fish, suggesting the role of WWTPs as an important source of fibers in estuaries. However, abandoned ropes, fishing gears (Browne et al. 2011) and atmospheric fallout of fibers (Dris et al. 2017) could be as potential sources of fiber contamination in the aquatic systems.

The characterization of the extracted particles involved an identification of the plastic component using micro-Raman spectroscopy. In the Raman spectrum of fibers, only fluorescence could be observed, although an optimization including the reduction of laser power and bleaching was attempted (see Kappler et al. 2016). Yet, when the sample is thin, Raman tends to detect the underlying substrate instead of the sample (Kappler et al. 2015) which explains the problem we had when identifying fibers' nature. Raman is able to achieve a better spatial resolution (down to $1 \mu \mathrm{m})$ than FT-IR $(10 \mu \mathrm{m})$ (Lenz et al. 2015) but the identification of fibers relies mainly on FTIR as Raman analyses did not prove to be efficient so far for this type of microplastics (Kappler et al. 2016). For the colored items, the spectrum was hidden by the additives (dyes) existing on particles. Even if these spectra were subtracted, polymers could not be identified due to the intense additives' spectra (Van Cauwenberghe et al. 2013; Van Cauwenberghe and Janssen 2014). This problem was discussed by many authors (see Collard et al. 2015; Lenz et al. 2015; Frère et al. 2016) and, therefore, preventing polymer identification. As the analysis of fibers was not conclusive with the Raman, most of the analyzed MP items were fragments. As previously mentioned, the majority of MP items identified were fibers so we only have a partial representation of the type of polymers ingested by flounders. A combination of identification 
techniques is necessary for a complete and reliable characterization of the chemical composition of plastics (Kappler et al. 2016; Hermabessiere et al. 2018). The types of polymers identified were Polycaprolactam (PA), Polyethylene Terephtalate (PET), and Polyurethane (PUR). Less dense MP such as polyethylene (PE) and PUR can be found on the surface or in the water column while denser plastics like PA and PET sink and reside primarily in sediments (Chubarenko et al. 2016). The presence of Polyurethane in fish caged in Rouen may be explained by the presence of numerous petrochemical industries in and near this site. Another explanation could be that this low dense polymer (PUR) may have sunk to the bottom since the site of Rouen is characterized by a low water density (salinity $=0.4$ ) compared to the other sites which are characterized by higher water salinity ranging from 17.5 at Fosse Nord and 30.5 at Le Havre Harbor. However, the buoyancy of microplastics can also be affected by chemical contaminants and biofouling.

To the best of our knowledge, all the studies that have investigated the ingestion of microplastics by fish have been conducted from wild caught species or in laboratory experiments. However, the migration of many fish species for feeding and breeding creates uncertainty about how well the analysis made on an individual truly reflects the environmental contamination by MP in or around the site of capture (Oikari 2006). In this study, we tested for the first time the feasibility of using caged juveniles to quantify and assess MP contamination of in estuarine nursery grounds. Such approach was successfully used to monitor microplastics contamination in mussels (Catarino et al. 2018; Railo et al. 2018). Our results demonstrated that the fish caging approach is suitable to assess MP contamination in estuaries and to a lesser extent their effects on fish condition. An average of 2.04 $\pm 1.93 \mathrm{MP}$ items was ingested by feral juveniles flounder and $1.67 \pm 1.43$ by caged juveniles flounder. Similar levels $(1.9 \pm 0.1$ items/individual) were previously reported for different adult fish species by Lusher et al. (2013) in the English Channel or in others estuaries: 1.67 items/individual (Bessa et al. 2018), 3.03 (Ferreira et al. 2018) and 1.06 (Vendel et al. 2017).

The higher number of fragments and fibers in wild fish when compared with the caged ones suggest that the latter are probably limited in their feeding zone and, therefore, will have a lower number of ingested items. During the caging experiment, most of the fish have lost weight and it is likely that food availability in the cages was rather low due to the limited cage dimension. The 
more frequent occurrence of MP in benthic species compared to pelagic fish (e.g. Neves et al. 2015; McGoran et al. 2017; Jabeen et al. 2017) suggests that plastic occurrence may be high near the sea floor and/or in sediments, or that benthic fish are less selective feeders. In the Thames estuary, McGoran et al. (2017) found that $70 \%$ of sampled European flounder had plastic fibers in their gut compared with only $20 \%$ of European smelt, Osmerus eperlanus (a pelagic species). The generalist feeding behavior of juvenile flounders which feed on benthic preys and ingest large quantities of sediment (Selleslagh and Amara 2015) suggest that everything is a potential prey to feed on, including microplastics being mistaken as food source.

In this study, we compared exposed juvenile fish from 5 sites in 3 different estuaries. Except the Liane and Fosse Nord, we did not observe significant differences in the number of MP ingested by caged fish. However, the three sites impacted by WWTP (Liane, Le Havre Harbor and Rouen) are those with the highest percentage of individuals that have ingested fibers. This suggest the possible contribution of WWTPs as a source of MP in estuaries.

While microplastic ingestion by fish has been confirmed in laboratory and wild caught specimens, we know little about the impact of MP consumption by fish. However, the quantities observed in fish guts are generally very low, usually less 1 to 2 particles per individual (Lusher et al. 2017). Although other environmental factors may have affected caged fish condition and mortality, we found no significant correlation between the condition factor and the mortality rate with the MP number ingested by fish. Other studies also found that the condition factor of wild captured fish was similar for those with or without MP ingestion (Ramos et al. 2012, Foekema et al. 2013). However, these results did not exclude the possibility of physiological and toxicological consequences. Risks associated with the ingested MP come from the material itself and from the chemical pollutants included in plastic such as additives or contaminants adsorbed from the surrounding water. Hazards associated with the complex mixture of plastic and accumulated pollutants are largely unknown (Browne et al. 2013; Lusher et al. 2017). Metabolic and physiological negative responses have been only observed under laboratory conditions, where in most cases; very high levels of microplastics were tested under exposure scenarios that were not representative of natural environmental conditions (e.g. Rochman et al. 2013; Peda et al. 2016; Critchell and Hoogenboom 2018 and review in Lusher et al. 2017). Recently microplastics were isolated in the gills, liver, and digestive tract of the Zebra danio (Danio 
rerio); which caused inflammation, oxidative stress, and disrupted energy metabolism (Lu et al. 2016). Rochman et al (2013) showed that Japanese medaka (Oryzias latipes), exposed to a mixture of polyethylene with chemical pollutants sorbed from the marine environment, can bioaccumulate these chemical pollutants leading to liver toxicity and pathology. Fish behavior may also be affected by microplastic exposure: the common goby (Pomatoschistus microps) displayed reduced predatory performance, abnormal swimming behavior, and lethargy (De Sa et al. 2015).

\section{Conclusion}

Regarding the present study, we can conclude that caged fish are suitable to assess microplastic contamination in aquatic environment. Both caged and wild caught European flounder from three estuaries of the Eastern English Channel ingested MP, mainly fibers, in an amount higher to that generally observed in other marine fish species. This would confirm previous studies that have indicated that MP are more common within estuaries than in the marine environment (Schmidt et al. 2017; Horton et al. 2017). European flounder is an opportunistic species that tolerates a wide range of salinity (0 to 35$)$ and can be an ideal indicator to study MP contamination along a salinity gradient. Since microplastic contamination may vary in space and time, particularly in estuarine systems affected by tide and river flow, the caging approach may be useful for assessing the spatial and temporal variability in MP and the many factors that influence this.

The high occurrence of MP ingested by juvenile fish in nursery grounds raises concerns on their potential negative effects for fish recruitment success and population renewal. No negative effects on juvenile fish condition was observed. However, further researches are required to fully understand the ecological impact of MP within these essential fish habitats. The caging approach may be useful to study the potential effect of MP ingestion on physiological and toxicological responses fish by measuring different biomarkers. 


\section{Acknowledgments}

Maria Kazour is financially supported by a $\mathrm{PhD}$ fellowship from the National Council for Scientific Research (Lebanon) and Université du Littoral Côte d'Opale (France). Ludvovic Hermabessiere is financially supported by a $\mathrm{PhD}$ fellowship granted by the Hauts-de-France Region and ANSES (French Agency for Food, Environmental and Occupational Health \& Safety). This paper has been realized in the projects Plastic-Seine and HQFISH funded by GIP Seine Aval and in the framework of the project CPER 2014-2020 MARCO funded by the French government and the Hauts-de-France Region. The authors would like to thank Rouen and Le Havre harbors' administration for giving us the permission to install the cages in the sampling sites and the divers' contribution (F. Gevaert, G. Duong; I. Richard and J.L. Lenne) for the cages' deployment.

\section{References}

Amara R, Selleslagh J, Billon G, Minier C (2009) Growth and condition of 0-group European flounder, Platichthys flesus as indicator of estuarine habitat quality. Hydrobiologia 627: 87-98. https://doi.org/10.1007/s10750-009-9717-9

Anderson ZT, Cundy AB, Croudace IW, Warwick PE, Celis-Hernandez O, Stead JL (2018) A rapid method for assessing the accumulation of microplastics in the sea surface microlayer (SML) of estuarine systems. Scientific reports 8(1): 9428. https://doi.org/10.1038/s41598-018-27612-w

Andrady AL (2011) Microplastics in the marine environment. Mar Pollut Bull 62: 1596-1605. https://doi.org/10.1016/i.marpolbul.2011.05.030

Au SY, Lee CM, Weinstein JE, van den Hurk P, Klaine SJ (2017) Trophic transfer of microplastics in aquatic ecosystems: Identifying critical research needs. Integr Environ Assess Manag 13(3): 505-509. https://doi.org/10.1002/ieam.1907

Auta HS, Emenike CU, Fauziah, SH (2017) Distribution and importance of microplastics in the marine environment: A review of the sources, fate, effects, and potential solutions. Environ Int 102: 165-176. https://doi.org/10.1016/j.envint.2017.02.013

Avio CG, Gorbi S, Regol F (2015) Experimental development of a new protocol for extraction and characterization of microplastics in fish tissues: First observations in commercial species from Adriatic Sea. Mar Environ Res 111: 18-26111. https://doi.org/10.1016/j.marenvres.2015.06.014

Beck MW, Heck Jr KL, Able KW, Childers DL, Eggleston DB et al (2001) The identification, conservation and management of estuarine and marine nurseries for fish and invertebrates. BioScience 51: 633-641. https://doi.org/10.1641/0006-3568(2001)051/0633:TICAMO]2.0.CO;2 
Bessa F, Barría P, Neto JM, Frias JPGL, Otero V, Sobral P, Marques JC (2018) Occurrence of microplastics in commercial fish from a natural estuarine environment. Mar Pollut Bull 128: 575-584. https://doi.org/10.1016/j.marpolbul.2018.01.044

Browne MA, Galloway TS, Thompson RC (2010) Spatial patterns of plastic debris along estuarine shorelines. Enviro Sci Technol 44: 3404-3409. https://doi.org/10.1016/10.1021/es903784e

Browne MA, Crump P, Niven ST, Teuten E, Tonkin A, Galloway T, Thompson R (2011) Accumulation of Microplastic on Shorelines Woldwide: Sources and Sinks. Environ Sci Technol 45(21): 9175-9179. https://doi.org/10.1021/es201811s

Browne MA, Niven SJ, Galloway TS, Rowland SJ, Thompson RC (2013) Microplastic moves pollutants and additives to worms, reducing functions linked to health and biodiversity. Current Biology 23(23): 2388-2392. https://doi.org/10.1016/j.cub.2013.10.012

Catarino Al, Macchia V, Sanderson WG, Thompson RC, Henry TB (2018) Low levels of microplastics (MP) in wild mussels indicate that MP ingestion by humans is minimal compared to exposure via household fibres fallout during a meal. Environ Pollut 237:675-684. https://doi.org/10.1016/i.envpol.2018.02.069

Chubarenko I, Bagaev A, Zobkov M, Esiukova E (2016) On some physical and dynamical properties of microplastic particles in marine environment. Mar Pollut Bull 108(1-2): 105-112. https://doi.org/10.1016/i.marpolbul.2016.04.048

Cole M, Lindeque P, Fileman E, Halsband C, Goodhead R, Moger J, Galloway TS (2013) Microplastic ingestion by zooplankton. Environ Sci Technol 47 (12): 6646-6655. https://doi.org/10.1021/es400663f

Cole M, Webb H, Lindeque PK, Fileman ES, Halsband S, Galloway TS (2014) Isolation of microplastics in biota-rich seawater samples and marine organisms. Sci Rep 4: 4528 . https://doi.org/10.1038/srep04528

Collard F, Gilbert B, Eppe G, Parmentier G, Das K (2015) Detection of anthropogenic particles in fish stomachs: an isolation method adapted to identification by Raman spectroscopy. Arch Environ Contam Toxicol 69: 331-339. https://doi.org/10.1007/s00244-015-0221-0

Courrat A, Lobry J, Nicolas D, Laffargue P, Amara R, Lepage M et al (2009) Anthropogenic disturbance on nursery function of estuarine areas for marine species. Estuar Coast Shelf Sci 81(2): 179-190. http://doi.org/10.1016/j.ecss.2008.10.017

Critchell K, Hoogenboom MO (2018) Effects of microplastic exposure on the body condition and behaviour of planktivorous reef fish (Acanthochromis polyacanthus). PLoS ONE 13(3): e0193308. https://doi.org/10.1371/journal.pone.0193308

Conley K (2017) The Removal of Microplastics by Wastewater Treatment Plants in Charleston, SC and a Survey of Treatment Processes. Doctoral dissertation, College of Charleston.

Dantas DV, Barletta M, Costa MF (2012) The seasonal and spatial patterns of ingestion of polyfilament nylon fragments by estuarine drums (Sciaenidae). Environ Sci Pollut Res 19: 600-606. https://doi.org/10.1007/s11356-011-0579-0 
Dauvin, JC, Ruellet T, Desroy N, Janson AL (2007) The ecological quality status of the Bay of Seine and the Seine estuary: use of biotic indices. Mar Pollut Bull 55(1-6): 241-257. http://doi/org.10.1016/j.marpolbul.2006.04.010

Dehaut A, Cassone AL, Frere L, Hermabessiere L, Himber C, Rinnert E et al (2016) Microplastics in seafood: Benchmark protocol for their extraction and characterization. Environ Pollut 215: 223-233. http://doi.org/10.1016/i.envpol.2016.05.018

De Sá LC, Luís LG, Guilhermino L (2015) Effects of microplastics on juveniles of the common goby (Pomatoschistus microps): confusion with prey, reduction of the predatory performance and efficiency, and possible influence of developmental conditions. Environ Pollut 196: 359-62. https://doi.org/10.1016/i.envpol.2014.10.026

Dris R, Gasperi J, Rocher V, Saad M, Renault N, Tassin B (2015) Microplastic contamination in an urban area: a case study in Greater Paris. Environ Chem 12(5): 592-599. https://doi.org/10.1071/EN14167

Dris R, Gasperi J, Mirande C, Mandin C, Guerrouache M, Langlois V, Tassin B (2017) A first overview of textile fibers, including microplastics, in indoor and outdoor environments. Environ Pollut 221: 453-458. https://doi.org/10.1016/j.envpol.2016.12.013

Ferreira GVB, Barletta M, Lima ARA, Morley SA, Justino AKS, Costa MF (2018) High intake rates of microplastics in a Western Atlantic predatory fish, and insights of a direct fishery effect. Environ Pollut 236: 706-717. https://doi.org/10.1016/i.envpol.2018.01.095

Foekema EM, De Gruijter C, Mergia MT, van Franeker JA, Murk ATJ, Koelmans AA (2013) Plastic in North Sea Fish. Environ Sci Technol 47 (15): 8818-8824. https://doi.org/10.1021/es400931b

Frère L, Paul-Pont I, Moreau J, Soudant P, Lambert C, Huvet A, Rinnert E (2016) A semi-automated Raman micro-spectroscopy method for morphological and chemical characterizations of microplastic litter. Mar Pollut Bull 113: 461-468. https://doi.org/ 10.1016/j.marpolbul.2016.10.051

Gall SC, Thompson RC (2015) The impact of debris on marine life. Mar Pollut Bull 92: 170-179. https://doi.org/10.1016/j.marpolbul.2014.12.041

Gallagher A, Rees A, Rowe R, Stevens J, Wright P (2016) Microplastics in the Solent estuarine complex, UK: an initial assessment. Mar Pollut Bull 102(2): 243-249. https://doi.org/10.1016/j.marpolbul.2015.04.002

Gilliers C, Le Pape O, Désaunay Y, Morin J, Guérault D, Amara R (2006) Are growth and density quantitative indicators of essential fish habitat quality? An application to the common sole Solea solea nursery grounds. Estuar Coast Shelf Sci (69): 96-106. http://doi.org/10.1016/i.ecss.2006.02.006

Güven O, Gokda K, Jovanovic B, Kıdeys AE (2017) Microplastic litter composition of the Turkish territorial waters of the Mediterranean Sea, and its occurrence in the gastrointestinal tract of fish. Environ Pollut 223: 286-294. http://doi.org/10.1016/i.envpol.2017.01.025

Gray AD, Wertz H, Leads RR, Weinstein JE (2018) Microplastic in two South Carolina Estuaries: Occurrence, distribution, and composition. Mar Pollut Bull 128: 223-233. https://doi.org/10.1016/j.marpolbul.2018.01.030 
Halpern BS, Walbridge S, Selkoe KA, Kappel CV, Micheli F, D'Agrosa C, Bruno JF et al (2008) A global map

565 of human impact on marine ecosystems. Science 319(5865): 948-52.

566 https://doi.org/10.1126/science.1149345

567 Hermabessiere L, Himber C, Boricaud B et al (2018) Optimization, performance, and application of a 568 pyrolysis-GC/MS method for the identification of microplastics. Anal Bioanal Chem p: 1-14. 569 https://doi.org/10.1007/s00216-018-1279-0

570 Hermsen E, Pompe R, Besseling E, Koelmans AA (2017) Detection of low numbers of microplastics in 571 North Sea fish using strict quality assurance criteria. Mar Pollut Bull 122: 253-258. 572 https://doi.org/10.1016/j.marpolbul.2017.06.051

573 Horton AA, Walton A, Spurgeon DJ, Lahive E, Svendsen C (2017) Microplastics in freshwater and 574 terrestrial environments: evaluating the current understanding to identify the knowledge gaps and 575 future research priorities. Sci Total Environ 586: 127-141. https://10.1016/i.scitotenv.2017.01.190

576 Ivar do Sul JA, Costa MF (2014) The present and future of microplastic pollution in the marine 577 environment. Environ Pollut 185: 352-364. https://doi.org/10.1016/i.envpol.2013.10.036

578 Jabeen K, Su L, Li J, Yang D, Tong C, Mu J, Shi H (2017) Microplastics and mesoplastics in fish from coastal 579 and fresh waters of China. Environ Pollut 221: 141-149. https://doi.org/10.1016/j.envpol.2016.11.055

580 Käppler A, Fischer D, Oberbeckmann S, Schernewski G, Labrenz M, Eichhorn KJ, Voit B (2016) Analysis of 581 environmental microplastics by vibrational microspectroscopy: FTIR, Raman or both?. Anal Bioanal 582 Chem 408(29): 8377-8391.

583 Käppler A, Windrich F, Löder MG, Malanin M, Fischer D, Labrenz M, Eichhorn KJ, Voit B (2015) 584 Identification of microplastics by FTIR and Raman microscopy: a novel silicon filter substrate opens the important spectral range below $1300 \mathrm{~cm}-1$ for FTIR transmission measurements. Anal Bioanal Chem 407(22): 6791-6801.

Kerambrun E, Sanchez W, Henry F, Amara R (2011) Are biochemical biomarker responses related to physiological performance of juvenile sea bass (Dicentrarchus labrax) and turbot (Scophthalmus maximus) caged in a polluted harbour?. Comp Biochem Physiol C Toxicol Pharmacol 154(3):187-95. https://doi.org/10.1016/j.cbpc.2011.05.006

591 Klein S, Worch E, Knepper TP (2015) Occurrence and spatial distribution of microplastics in river shore 592 sediments of the Rhine-Main area in Germany. Environ Sci Technol 49: 6070-6076. 593 https://doi.org/10.1021/acs.est.5b00492

594 Lenz R, Enders K, Stedmon CA, Mackenzie DM, Nielsen TG (2015) A critical assessment of visual 595 identification of marine microplastic using Raman spectroscopy for analysis improvement. Mar Pollut 596

597 Leslie HA, Brandsma SH, Van Velzen MJ, Vethaak AD (2017) Microplastics en route: Field measurements 598 in the Dutch river delta and Amsterdam canals, wastewater treatment plants, North Sea sediments and 599 biota. Environ Int 101: 133-142. https://doi.org/10.1016/i.envint.2017.01.018

600 Lönnstedt OM, Eklöv P (2016) Environmentally relevant concentrations of microplastic particles 601 influence larval fish ecology. Science 352: 1213-1216. https://doi.org/10.1126/science.aad8828 
Lu Y, Zhang Y, Deng Y, Jiang W, Zhao Y, Geng J, Ding L, Ren H (2016) Uptake and accumulation of polystyrene microplastics in zebrafish (Danio rerio) and toxic effects in liver. Environ Sci Technol 50: 4054-4060. https://doi.org/10.1021/acs.est.6b00183

Luís LG, Ferreira P, Fonte E, Oliveira M, Guilhermino, L (2015) Does the presence of microplastics influence the acute toxicity of chromium (VI) to early juveniles of the common goby (Pomatoschistus microps)? A study with juveniles from two wild estuarine populations. Aquat Toxicol 164: 163-174. https://doi.org/10.1016/j.aquatox.2015.04.018

Lusher AL, McHugh M, Thompson RC (2013) Occurrence of microplastics in the gastrointestinal tract of pelagic and demersal fish from the English Channel. Mar Pollut Bull 67(1-2): 94-9. https://doi.org/10.1016/i.marpolbul.2012.11.028.

Lusher AL, Hollman PCH, Mendoza-Hill JJ (2017) Microplastics in fisheries and aquaculture: status of knowledge on their occurrence and implications for aquatic organisms and food safety. FAO Fisheries and Aquaculture Technical Paper. No. 615. Rome, Italy.

Marchand J, Tanguy A, Laroche J, Quiniou L, Moraga D (2003) Responses of European flounder Platichthys flesus populations to contamination in different estuaries along the Atlantic coast of France. Mar Ecol Prog Ser 260: 273-284. https://doi.org/10.3354/meps260273

McGoran AR, Clark PF, Morritt D (2017) Presence of microplastic in the digestive tracts of European flounder, Platichthys flesus, and European smelt, Osmerus eperlanus, from the River Thames. Environ Pollut 220: 744-751. https://doi.org/10.1016/j.envpol.2016.09.078

McLusky D, Elliott M (2004) The Estuarine Ecosystem. Ecology, Threats and Management. Oxford University Press. https://doi.org/10.1093/acprof:oso/9780198525080.001.0001

Nadal MA, Alomar C, Deudero S (2016) High levels of microplastic ingestion by the semipelagic fish bogue Boops boops (L.) around the Balearic Islands. Environ Pollut 214:517-523. https://doi.org/10.1016/j.envpol.2016.04.054

Neves D, Sobral P, Ferreira JL, Pereira T (2015) Ingestion of microplastics by commercial fish off the Portuguese coast. Mar Pollut Bull 101:119-126. https://doi.org/10.1016/i.marpolbul.2015.11.008

Oikari A (2006) Caging techniques for field exposures of fish to chemical contaminants. Aquat Toxicol 78: 370-387. https://doi.org/10.1016/j.aquatox.2006.03.010

Pedà C, Caccamo L, Fossi MC, Gai F, Andaloro F, Genovese L, Perdichizzi A, Romeo T, Maricchiolo G (2016) Intestinal alterations in European sea bass Dicentrarchus labrax (Linnaeus, 1758) exposed to microplastics: preliminary results. Environ 212:251-256. https://doi.org/10.1016/j.envpol.2016.01.083

Possatto FE, Barletta M, Costa MF, Ivar do Sul JA, Dantas DV (2011) Plastic debris ingestion by marine catfish: an unexpected fisheries impact. Mar Pollut Bull, 62: 1098-1102. https://doi.org/10.1016/j.marpolbul.2011.01.036

Railo S, Talvitie J, Setälä O, Koistinen A, Lehtiniemi M (2018) Application of an enzyme digestion method reveals microlitter in Mytilus trossulus at a wastewater discharge area. Mar Pollut Bull 130: 206-214. . https://doi.org/10.1016/i.marpolbul.2018.03.022 
640 Ramos JAA, Barletta M, Costa MF (2012) Ingestion of nylon threads by Gerreidae while using a tropical 641 estuary as foraging grounds. Aquatic Biol 17: 29-34. https://doi.org/10.3354/ab00461

642 Rochman CM, Hoh E, Kurobe T, Teh SJ 2013 Ingested plastic transfers hazardous chemicals to fish and 643 induces hepatic stress. Scientific Reports 3: 3263. http://dx.doi.org/10.1038/srep03263

644 Romeo T, Pietro B, Pedà C, Consolia P, Andaloro F, Fossic MC (2015) First evidence of presence of plastic 645 debris in stomach of large pelagic fish in the Mediterranean Sea. Mar Pollut Bull 95: 358-36. 646 https://doi.org/10.1016/j.marpolbul.2015.04.048

647 Schmidt C, Krauth T, Wagner S (2017) Export of Plastic Debris by Rivers into the Sea. Environ Sci Technol 648 51: 12246-12253. https://doi.org/10.1021/acs.est.7b02368

649 Selleslagh J, Amara R (2008) Environmental factors structuring fish composition and assemblages in a 650 small macrotidal estuary (Eastern English Channel). Estuar Coast Shelf Sci 79: 507-517. 651 https://doi.org/10.1016/j.ecss.2008.05.006

652 Selleslagh J, Amara R, Laffargue P, Lesourd S, Lepage M, Girardin M (2009) Fish composition and 653 assemblage structure in three Eastern English Channel macrotidal estuaries: A comparison with other 654 French estuaries. Estuar Coast Shelf Sci 81: 149-159. https://doi.org/10.1016/j.ecss.2008.10.008

655 Selleslagh J, Amara R (2015) Are estuarine fish opportunistic feeders? The case of a low anthropized 656 nursery ground (the Canche Estuary, France). Estuaries and coasts 38(1): 252-267. 657 https://doi.org/10.1007/s12237-014-9787-4

658 Setälä O, Lehtiniemi M, Coppock R, Cole M (2018) Microplastics in Marine Food Webs. In: Microplastic 659 Contamination in Aquatic Environments pp. 339-363. https://doi.org/10.1016/B978-0-12-813747$660 \quad \underline{5.00011-4}$

661 Van Cauwenberghe L, Devriese L, Galgani F, Robbens J, Janssen CR (2015) Microplastics in sediments: A 662 review of techniques, occurrence and effects. Mar Environ Res 11:5-17. 663 https://doi.org/10.1016/j.marenvres.2015.06.007

664 Van Cauwenberghe L, Janssen CR (2014) Microplastics in bivalves cultured for human consumption. 665 Environ Pollut 193: 65-70. https://doi.org/10.1016/j.envpol.2014.06.010

666 Van Cauwenberghe L, Vanreusel A, Mees J, Janssen CR (2013) Microplastic pollution in deep-sea 667 sediments. Environ Pollut 182: 495-499. https://doi.org/10.1016/i.envpol.2013.08.013

668 Vendel AL, Bessa F, Alves VEN, Amorim ALA, Patrício J, Palma ART (2017) Widespread microplastic 669 ingestion by fish assemblages in tropical estuaries subjected to anthropogenic pressures. Mar Pollut Bull 670 117(1-2):448-455. https://doi.org/10.1016/i.marpolbul.2017.01.081

671 Wright SL, Thompson RC, Galloway TS (2013) The physical impacts of microplastics on marine 672 organisms: a review. Environ Pollut 178: 483-492. https://doi.org/10.1016/j.envpol.2013.02.031

673 Woodall LC, Sanchez-Vidal A, Canals M, Paterson GL et al (2014) The deep sea is a major sink for 674 microplastic debris. R Soc Open Sci 1:140317. https://doi.org/1098/rsos.140317 


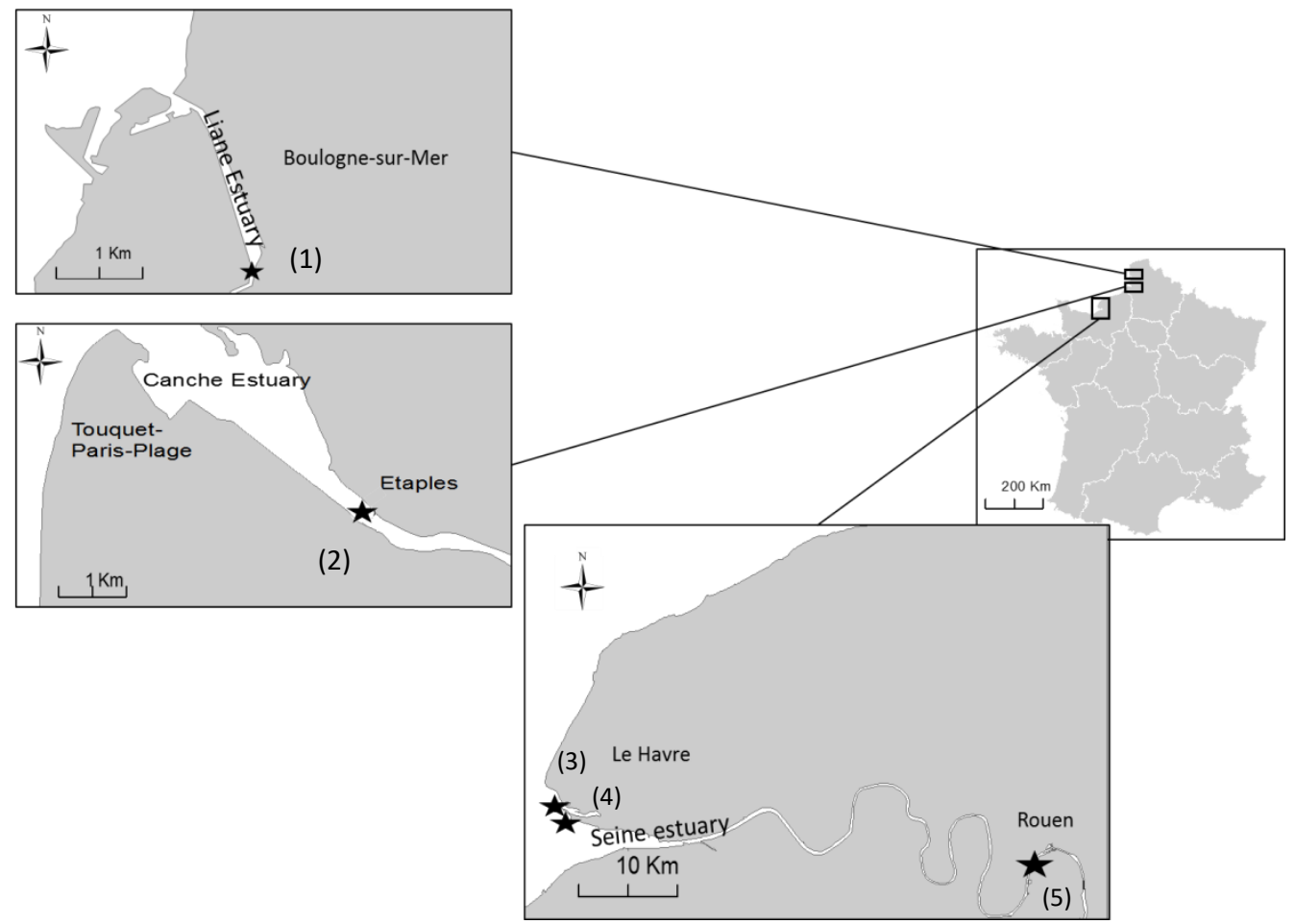

Fig. 1 Sampling and caging sites of juveniles flounder in (1) the Liane, (2) the Canche, and the Seine estuary: (3) Le Havre Harbor, (4) Fosse Nord and (5) Rouen 


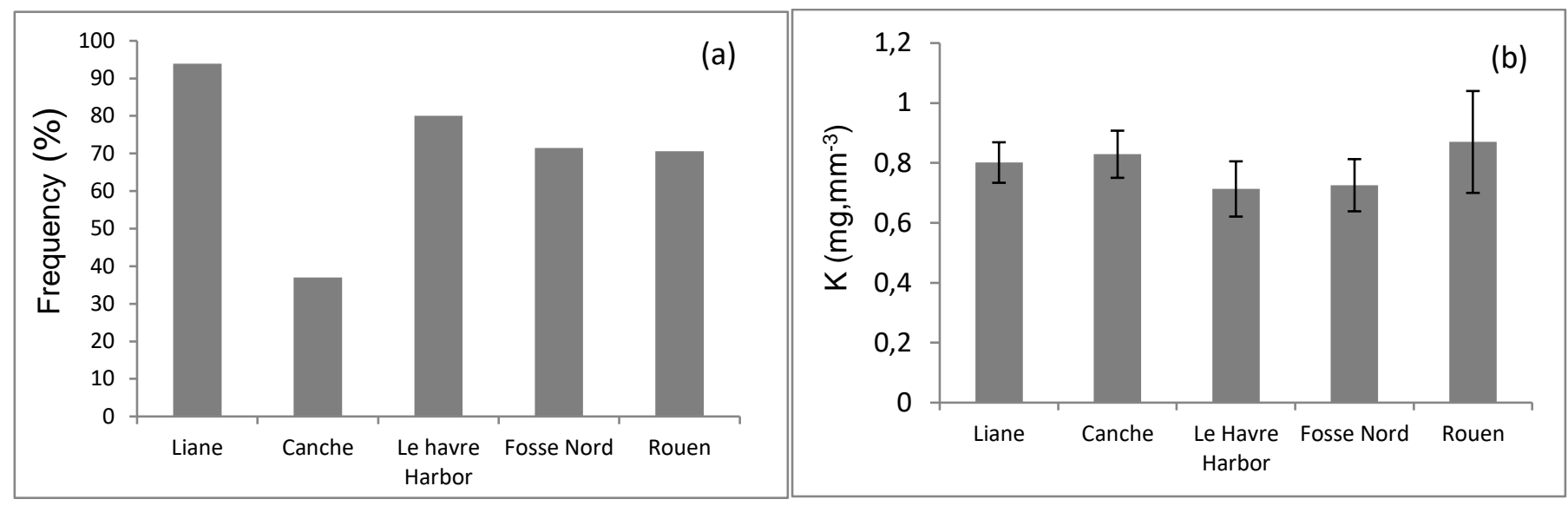

Fig. 2 Percentage of survival of juvenile flounder following one month caging experiment at the different sites (a) and, (b) Fulton $\mathrm{K}$ condition factor (mean $\pm \mathrm{SD}$ ) 


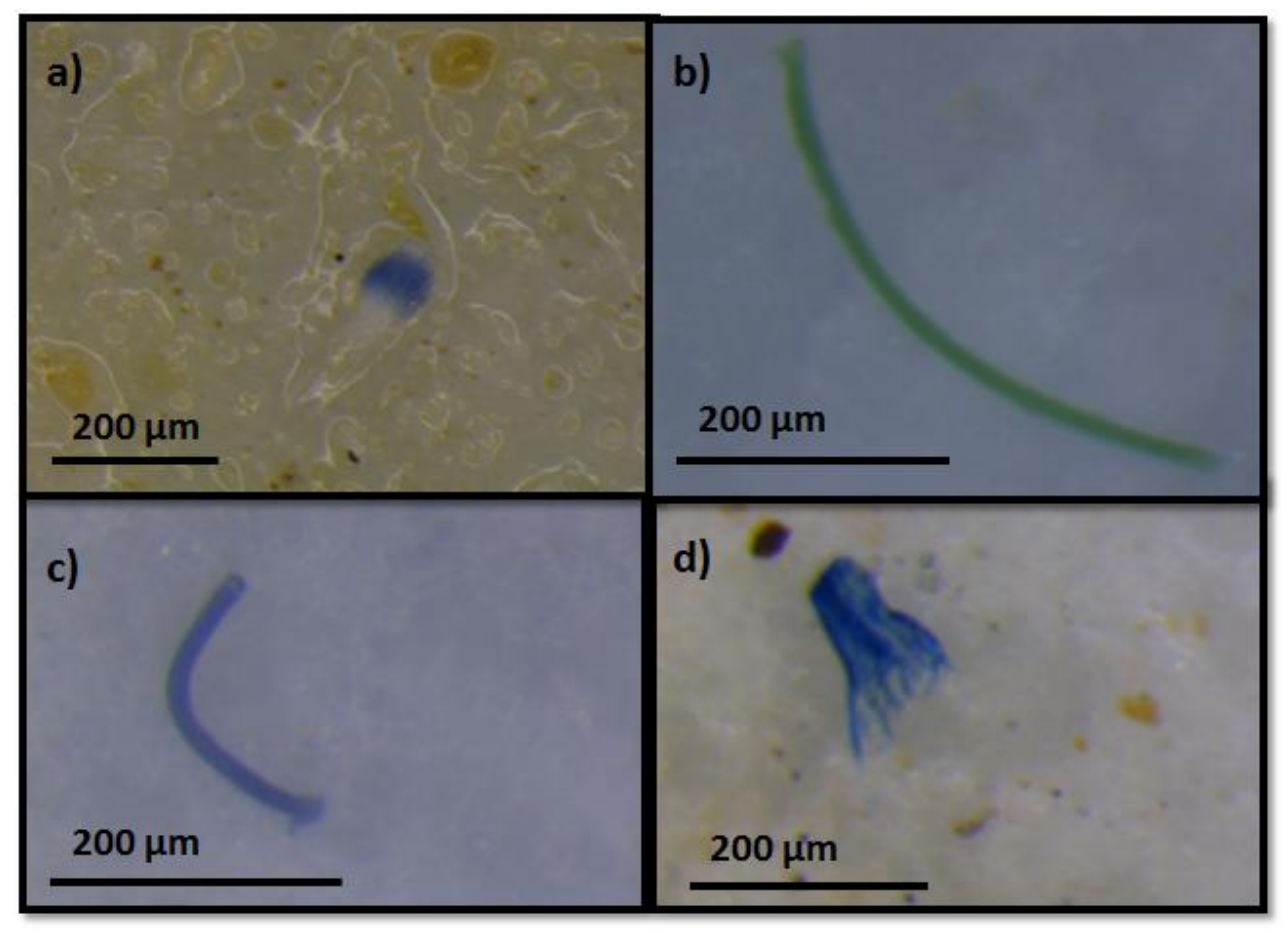

Fig. 3 Examples of microplastics found in the digestive tract of juveniles flounder: a) represents a fragment; $b$ ) and c) filaments; and d) films 


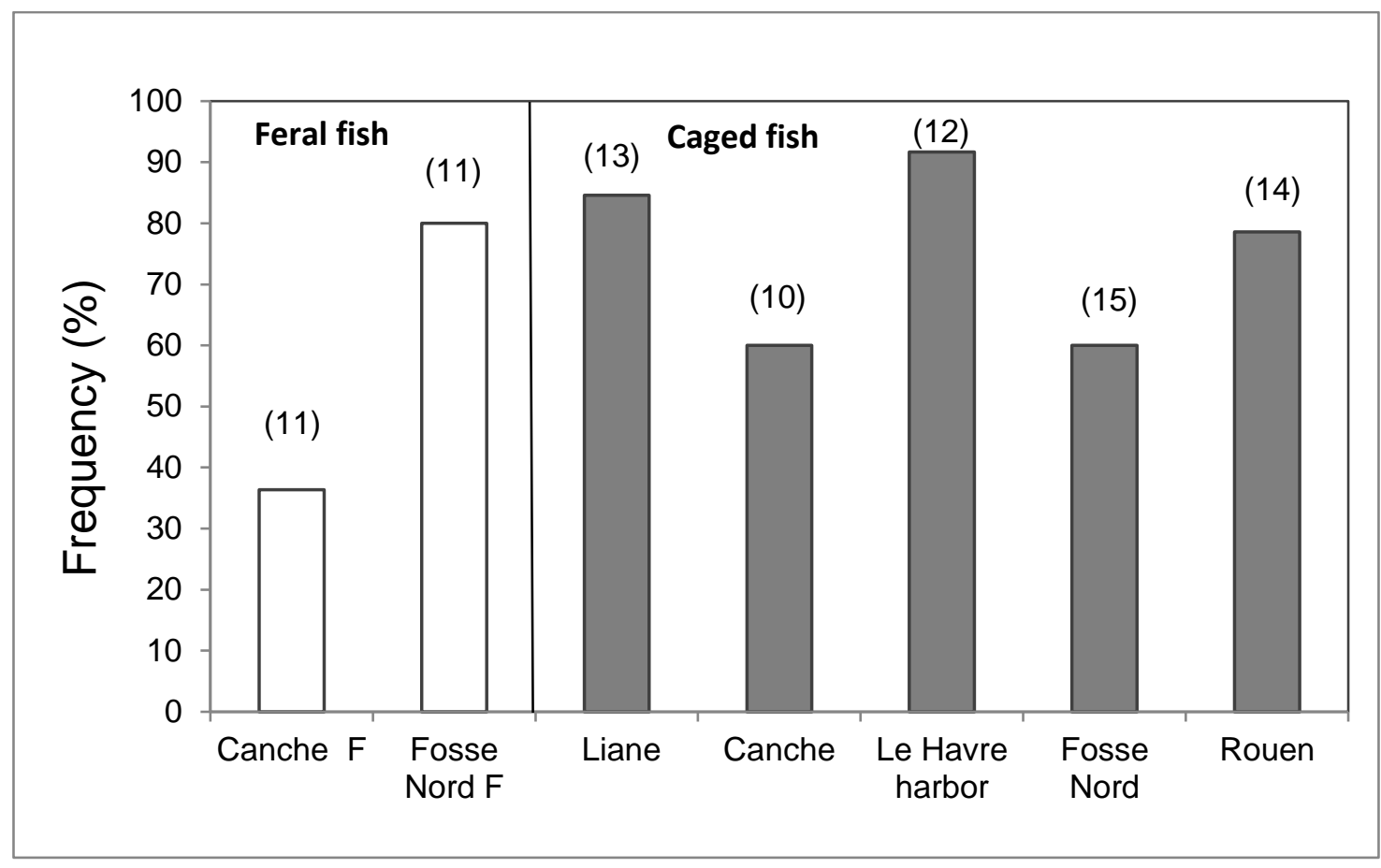

Fig. 4 Percentage of juvenile flounder that have ingested items. White bars: feral fish and grey bars: caged fish. Between brackets are presented the total number of analyzed individuals 


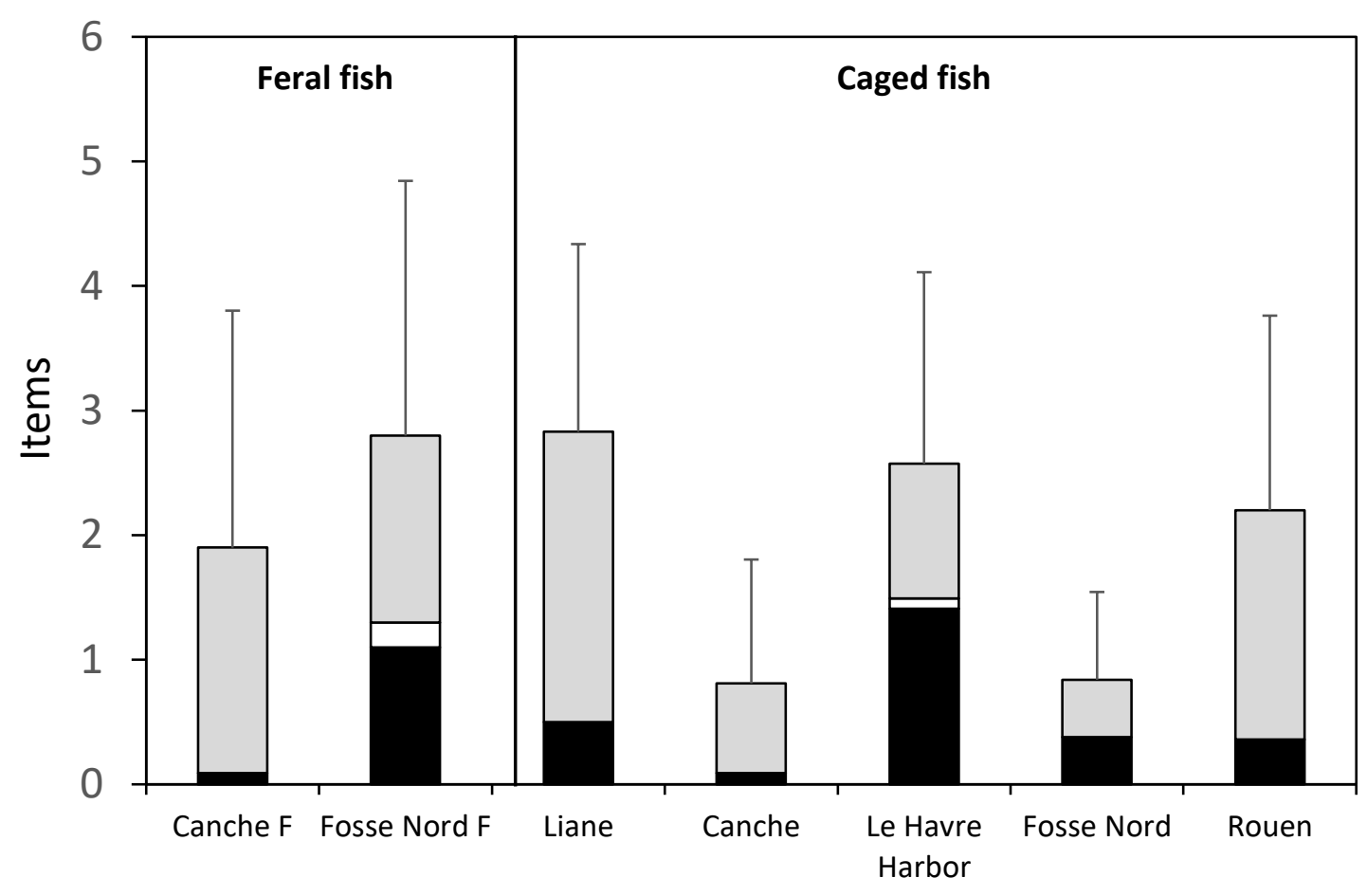

Fig. 5 Average (+ SD) number of items (fragments, fibers, and films) ingested by feral and caged juveniles flounder at the different estuarine sites. Grey: fibers; black: fragments; white: films 

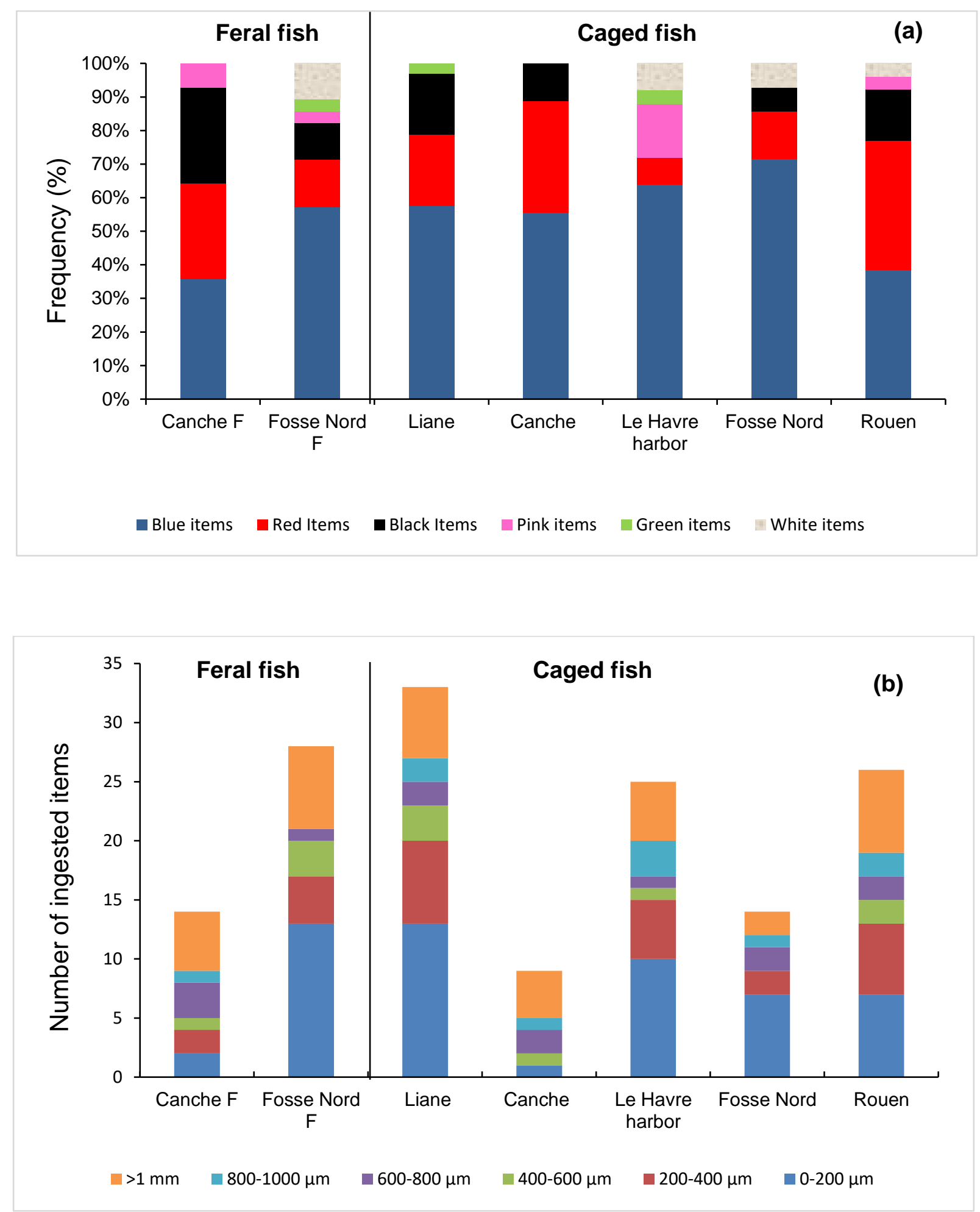

Fig. 6 Percentage of items ingested by feral and caged juvenile flounders at the different estuarine sites categorized by color (a) and the number of items ingested sorted by size class (b) 


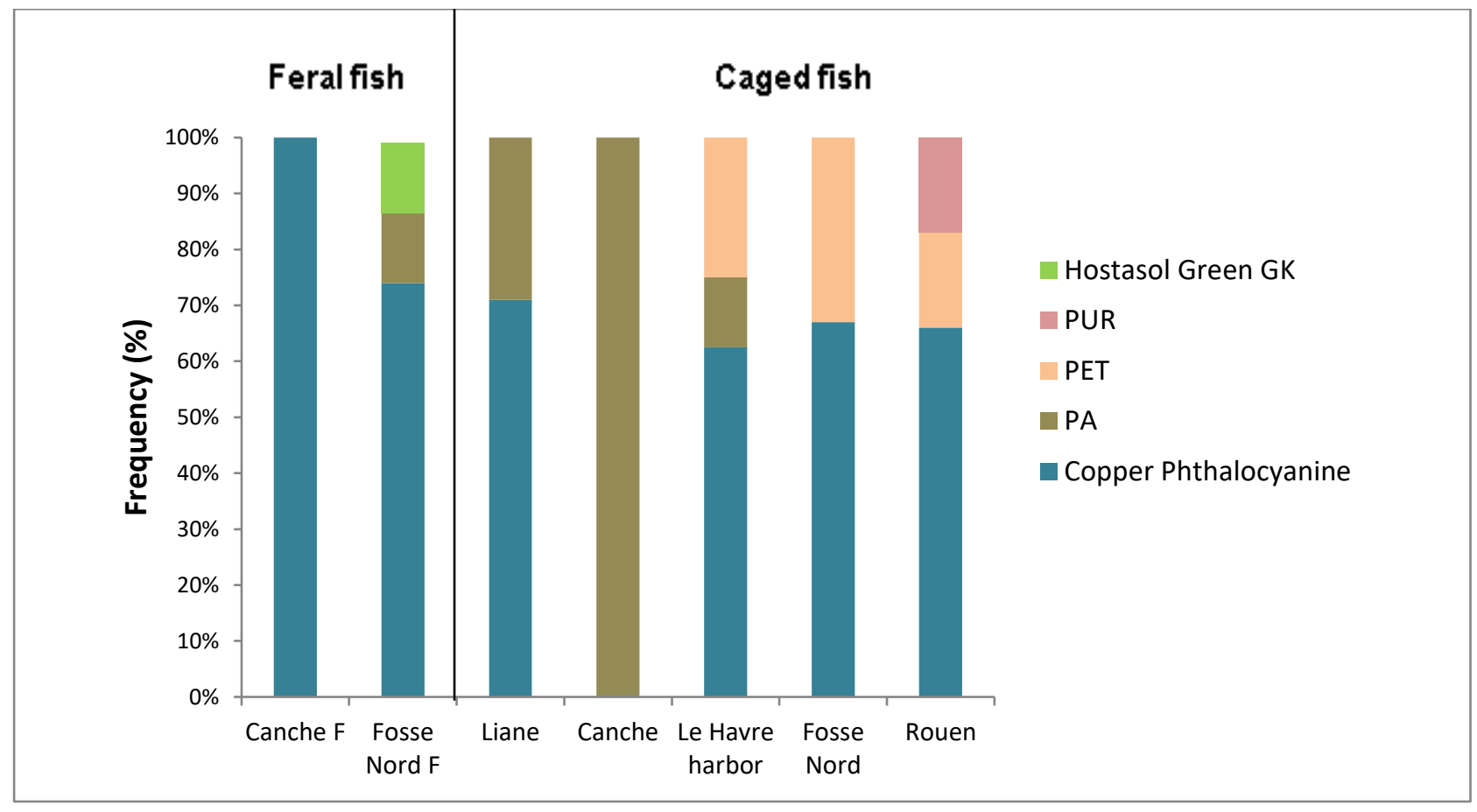

Fig. 7 Different polymers ingested by juvenile flounders (feral and caged) identified using micro-Raman spectroscopy 

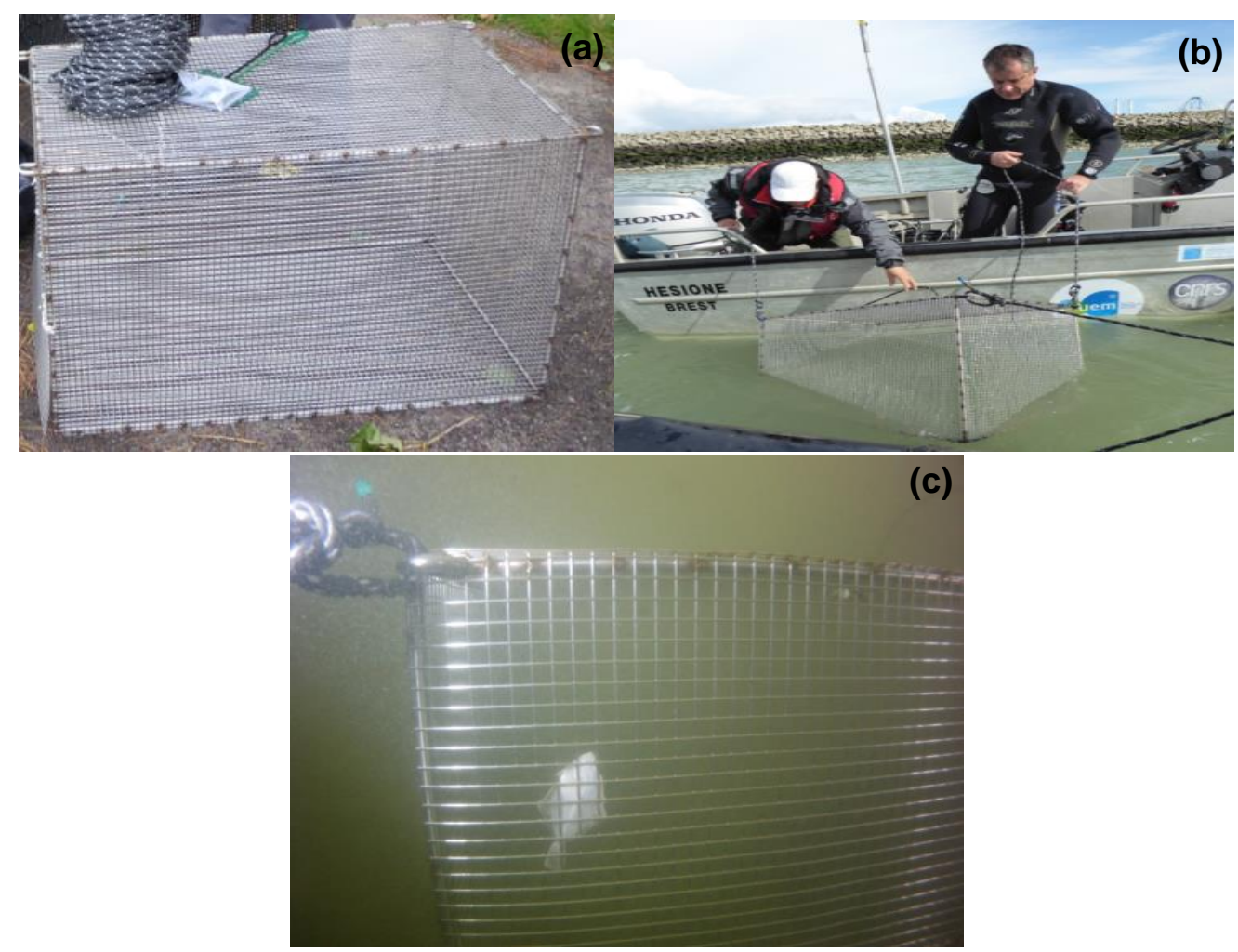

Fig. 1 The caging setup with (a) representing the stainless steel cage of $1 \mathrm{~m}$ length and a $0.6 \mathrm{~m}$ height and width. (b) representing the cage deployment and (c) representing Platichthys flesus swimming inside the cage after its attachment to the bottom 

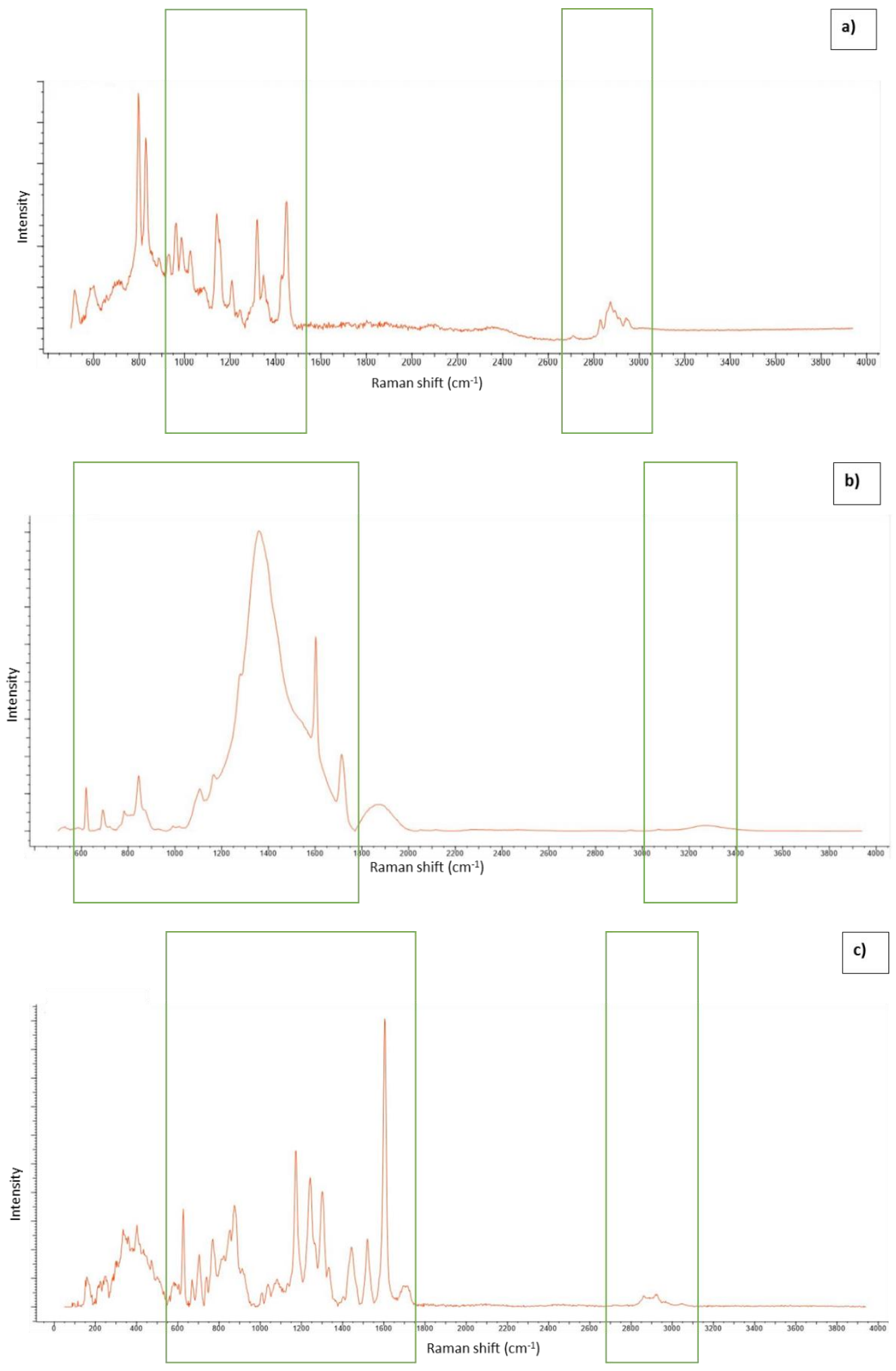


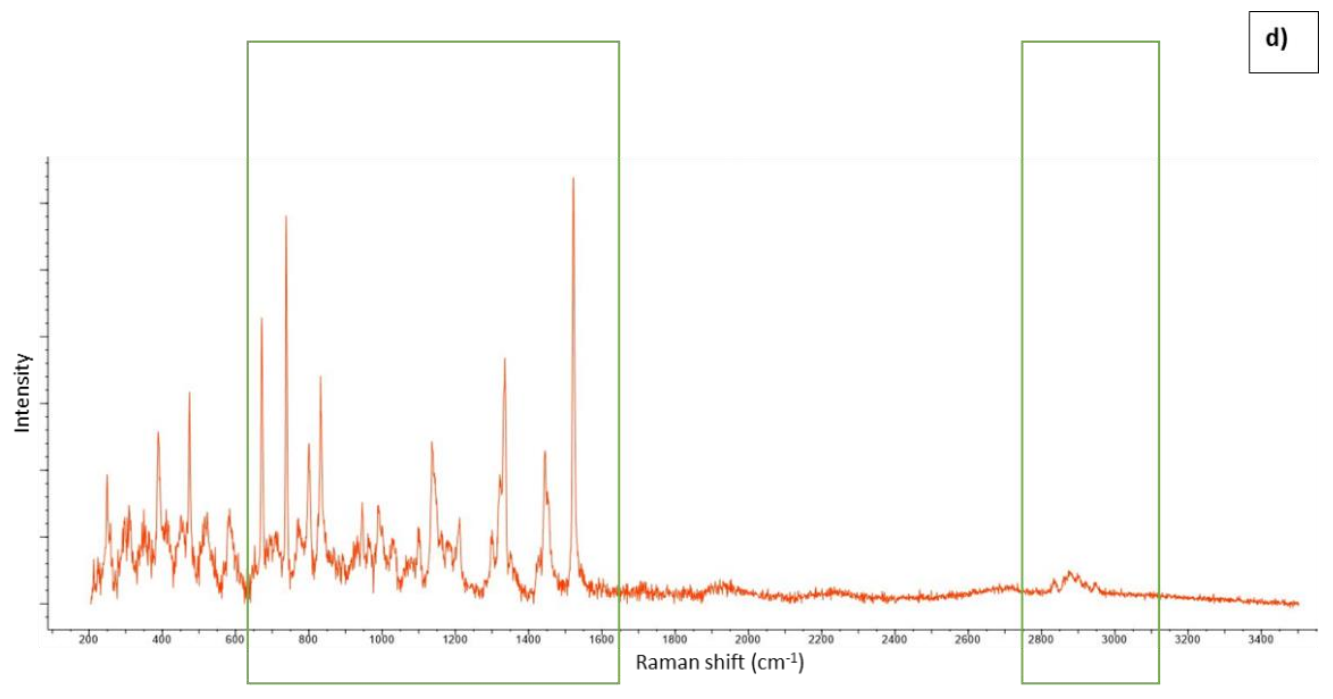

Fig. 2 Spectrum of Polycaprolactam (a), Polyethylene Terephtalate (b), Polyurethane (c), and Copper Phthalocyanine (d) obtained by micro-Raman spectroscopy 